\title{
Sáng tác song ngữ Pháp - Hán: một hiện tượng độc đáo trong văn học Việt Nam cuối thế kỷ XIX
}

\author{
Nguyễn Công $L \dot{y}^{a^{*}}$ \\ ${ }^{a}$ Khoa Văn hoc, Trưòng ĐHKHXH\&NV-ĐHQG TP.HCM \\ *Email: nguyencongly54@yahoo.com.vn
}

\section{Thông tin bài viết}

Ngày nhận bài:

16/02/2018

Ngày duyệt đăng:

$10 / 3 / 2018$

\section{Tù khoá:}

Sáng tác song ngũ Pháp Hán, Nguyễn Trọng Hiệp, Đại Pháp quốc Pa-ri đô thành tập vịnh, Chánh súr đoàn sang Pháp, viết năm 1894, xuất bản năm 1897.

\section{Tóm tắt}

Sáng tác bằng song ngữ không phải là chuyện hiếm trong văn chương ở nước ta và trên thế giới. Riêng ở Việt Nam từ đầu thế kỷ XVIII đến cuối thế kỷ XIX, đã có nhiều tác giả sáng tác bằng chữ Hán rồi tự dịch sang chữ Nôm, hoặc ngược lại, hay xen kẽ Hán - Nôm. Nhưng sáng tác bằng chữ Hán rồi chuyển ngữ sang Pháp văn, rồi xuất bản thành tập, in theo công nghệ hiện đại là một trường hợp hiếm có, độc đáo, chưa từng thấy trước đó, mà Nguyễn Trọng Hiệp có thể là tác giả tiên phong của hiện tượng này. Bài viết này sẽ giới thiệu trường hợp vừa nêu qua tập thơ song ngữ Pháp - Hán "Đại Pháp quốc Pa-ri đô thành tập vịnh" của Nguyễn Trọng Hiệp sáng tác năm 1894 trong chuyến công cán nước Pháp với tư cách là Chánh sứ, và xuất bản năm 1897.

\section{Giới thiệu}

Việc sáng tác bằng hai dạng ngôn ngữ (song ngữ) không phải là chuyện lạ trong văn học các nước trên thế giới, ngay cả ở Việt Nam thời trung đại cũng đã có vài trường hợp, đặc biệt là hồi đầu thế kỷ XVIII cho đến cuối thế kỷ XIX đã có một số tác giả sáng tác bằng chữ Hán rồi tự dịch sang chữ Nôm hoặc xen kẽ Hán - Nôm, như tác phẩm của Nguyễn Tông Quai, Đinh Nhật Thận, Nguyễn Khuyến... chẳng hạn. Nhưng sáng tác bằng chữ Hán rồi chuyển dịch sang tiếng Pháp, cho in thành tập và xuất bản theo công nghệ in hiện đại lúc bấy giờ (in typo - lithographque) là một trường hợp hiếm có, chưa từng thấy, mà theo tôi đây là một trường hợp độc đáo của Nguyễn Trọng Hiệp ${ }^{1}$, một vị quan đại thần dưới triều nhà Nguyễn.

\footnotetext{
${ }^{1}$ Chữ 合 chính âm đọc là "Họ̣p", còn đọc là "Hiệp". Theo bản in năm 1897 ở trang bìa có ghi chữ Pháp và chữ Quốc ngữ tên tác giả là Nguyễn Trọng Hiệp và trong trang bìa ruột chữ Hán có ghi: 文 明殿大學士永忠子金江阮仲合著 (Văn minh điện Đại học sĩ Vĩnh Trung tử Kim Giang Nguyễn Trọng Hiệp trước). Như vậy, tên của tác giả phải đọc là Hiệp, dù hiện nay trong rất nhiều tư liệu, trong
}

Tập thơ viết về thủ đô Pari trong một chuyến đi sứ với tư cách tác giả là Chánh sứ đại diện triều đình nước Đại Nam đi sang Pháp vào năm 1894. Tập thơ có nhan đề "Paris capitale de la France - Recueil de vers” 大法國玻璃都城集詠 Hanoi - Imprimerie Typo - Lithographque F. H. Schneider, 1897. (Đại Pháp quốc Pa-ri đô thành tập vịnh ${ }^{2}$ - Tuyển tập thơ vịnh về

đó có bản dịch bộ Sử triều Nguyễn và tập Kỷ yếu HTKH do Hội Sử học Hà Nội tổ chức "Nguyễn Trọng Họp" con người và sư nghiệp" đều đọc tên tác giả là Nguyễn Trọng Họ̣p. Theo tôi, tên nhân vật lịch sử - nhà thơ này nên đọc là "Hiệp" y như trên trang bìa tập thơ có ghi bằng chữ quốc ngữ là Nguyễn Trọng Hiệp 阮仲合.

${ }^{2}$ Pha-li (Ba-lê) 玻璃 phiên âm địa danh Paris (Pa-ri). Chữ “tập" 集 (trong "văn tập", "thi tập"), ở nguyên tác bản in năm 1897 có thêm bộ "kỳ" "k ở bên trái, mà tự dạng này, hiện nay rất thấy ít dùng. Tập thơ song ngữ Pháp-Hán này được TS. Phạm Văn Quang (nguyên Trưởng khoa Khoa Ngữ văn Pháp, Trường ĐHKHXH\&NV-ĐHQG TP HCM) chụp lại từ thư viện ở Cộng hoà Pháp.

Nhân đây tôi xin cám ơn TS. Phạm Văn Quang đã cung cấp ấn bản scane tập thơ này. Và xin cám ơn TS. Vương Thị Hường, Phó Tổng biên tập Tạp chí Hán Nôm đã cung cấp bản photo nguyên tác Tây tra thi thảo 西楂詩草 của Nguyễn Trọng Hiệp, ký hiệu VHv 1411. 
thủ đô Pa-ri của nước Pháp, nhà in ty-pô li-tô F. H. Schneider, Hà Nội, xuất bản năm 1897).

Theo tình hình tư liệu hiện nay có thể khẳng định đây là tập thơ song ngữ Pháp - Hán đầu tiên trong lịch sử văn học Việt Nam. Tập thơ gồm 36 bài thơ thất ngôn tứ tuyệt Đường luật, mà ở từng mỗi bài phần trên là thơ tiếng Pháp và ghi chú bằng tiếng Pháp, phần dưới là thơ chữ Hán và ghi chú cũng bằng chữ Hán. Đọc kỹ từng bài, có thể thấy thơ và ghi chú bằng tiếng Pháp là chuyển ngữ từ thơ và ghi chú bằng chữ Hán. Có thể Nguyễn Trọng Hiệp sáng tác bằng chữ Hán trước (vốn đây là công việc quá quen thuộc của các bậc khoa bảng), sau đó mới dịch sang tiếng Pháp, nhưng khi in thì nhà in cho in tiếng Pháp trước, chữ Hán sau.

Bài viết này sẽ giới thiệu tập thơ song ngữ Pháp Hán độc đáo trên của văn học Việt Nam hồi cuối thế kỷ XIX.

\section{Vài nét về tác giả}

Lần theo những ghi chép trong Đại Nam chính biên liệt truyện 大南正編列傳 (Quyển 30, Mục 20); và ở nhiều điều trong nhiều quyển của hai bộ sử: Đại Nam thưc luc chính biên - đẹ ngũ kỷ 大南定錄正編第 五紀 và Đại Nam thục lục chính biên - đệ lục kỷ Phụ biên 大南定錄正編第六紀附編 của Quốc sử quán triều Nguyễn do hai vị Tổng tài Hồ Đắc Trung và Võ Liêm, Toản tu Cao Xuân Tiếu... phụng chỉ biên soạn; tiểu sử vắn tắt được ghi trong Luợc truyện các tác gia Việt Nam do nhà thư tịch học Trần Văn Giáp chủ biên; trong Quốc triều đăng khoa lục 國朝登科錄 do Tổng đốc Sơn Hưng Tuyên Cao Xuân Dục biên soạn đầu thế kỷ XX, ta có thể nêu lại tiểu sử và sự nghiệp của Nguyễn Trọng Hiệp như sau:

Ông vốn tên là Nguyễn Tuyên 阮諠, tự Trọng Hiệp 仲合, hiệu Kim Giang 金江, khi đi thi ông mới lấy tên tự làm tên chính thức, quê ở xã Kim Lũ, huyện Thanh Trì, tỉnh Hà Nội. Ông sinh năm Giáp Ngọ $(1834)^{3}$, xuất thân trong một gia đình khoa bảng, ông tổ năm đời là Nguyễn Công Thái (Nguyễn Công Thể) đậu Tiến sĩ, làm quan dưới triều Lê trung hưng đến tước Quận công, hàm Thái phó. Năm 25 tuổi, Nguyễn

\footnotetext{
${ }^{3}$ Trong bộ Đại Nam thực lục chính biên đệ lục kỷ Phu biên (Cao Tự Thanh dịch và giới thiệu, Nxb Văn hoá - Văn nghệ Tp. HCM, 2011, tr. 172), dù bộ sử này không chép cụ thể về năm sinh nhưng căn cứ vào quyển thứ 5 có chép việc triều đình ban tặng phẩm vật mừng thọ Nguyễn Trọng Hiệp 60 tuổi vào tháng 2 năm Quý Tỵ Thành Thái thứ 5 (dương lịch 1893), từ đó ta có thể suy ra năm sinh của ông là năm Giáp Ngọ (1834).
}

Trọng Hiệp thi đậu Cử nhân khoa Mậu Ngọ (1858), rồi nhiều năm sau, kỳ chính khoa khoa Ât Sửu (1865), ông dự thi Hội và thi Đình, đỗ Đệ Tam giáp đồng Tiến sĩ xuất thân, tên ghi đứng đầu giáp thứ ba này ${ }^{4}$, niên hiệu Tự Đức năm thứ 18 (1865). Ông mất năm Nhâm Dần niên hiệu Thành Thái thứ 14 (1902), hưởng thọ 69 tuổi. Ông làm quan trải qua các đời vua: Tự Đức (1847-1883), Dục Đức (1883), Hiệp Hòa (1883), Kiến Phúc (1884), Hàm Nghi (1884-1888), Đồng Khánh (1885-1888), Thành Thái (1889-1907). Thời điểm ông đi thi, đỗ đạt và làm quan dưới triều Nguyễn chính là lúc đất nước đã và đang diễn ra nhiều biến động dữ dội: Pháp xâm lược, đất nước mất dần vào tay thực dân: ba tỉnh miền Đông (hòa ước Nhâm Tuất 1862), ba tỉnh miền Tây (hòa ước Giáp thân 1874), rồi hòa ước Giáp Thân (hòa ước Patenottre) năm 1884 thì Nam Kỳ trở thành thuộc địa, Bắc kỳ và Trung Kỳ trở thành xứ bảo hộ, riêng hai thành phố Đà Nẵng và Hải Phòng là nhượng địa. Đây cũng là lúc mà trong vòng 2 năm $(1883,1884)$ có đến 4 vị vua: Dục Đức, Hiệp Hoà, Kiến Phúc, Hàm Nghi lần lượt nối ngôi. Lúc này nội bộ triều đình thì phân hoá, chia làm hai phe rõ rệt: phe chủ chiến (tức chống Pháp) mà người đứng đầu là

\footnotetext{
${ }^{4}$ Năm này, triều đình cho mở hai khoa: một chính khoa và một ân khoa: Khoa Nhã sĩ. Theo Quốc triều đăng khoa lục của cụ Tử Phát Cao Xuân Dục thì chính khoa lấy đỗ 16 người, trong đó có 03 chánh bảng ( 01 Nhị giáp, 02 Tam giáp) và 13 Phó bảng. Khoa Nhã sĩ lấy đỗ 05 người, trong đó có 01 đệ Nhất giáp Tiến sĩ đệ Tam danh (Thám hoa) và 04 đệ Nhị giáp (Hoàng giáp). Nguyễn Trọng Hiệp thi đậu đệ Tam giáp đồng Tiến sĩ xuất thân kỳ chính khoa Ất Sửu, tên đứng đầu bảng đệ Tam giáp, và người đỗ Đình nguyên khoa này là Đệ Nhị giáp Tiến sĩ xuất thân (Hoàng giáp) Trần Bích San. Nhưng trong bộ Đại Nam thưc luc chính biên đệ lục kỷ Phu biên ghi ông đậu Tiến sĩ đệ Nhất danh là không chính xác (sđđ, bản dịch, tr. 385), Khi gọi Tiến sĩ đệ Nhất danh (hay Tiến sĩ cập đệ đệ Nhất danh) tức Trạng nguyên, bởi học vị xếp loại kỳ thi Đình vào các triều đại Lê, Nguyễn như sau: Đệ Nhất giáp Tiến sĩ cập đệ có ba vị là đệ Nhất danh (Trạng nguyên), đệ Nhị danh (Bảng nhãn), đệ Tam danh (Thám hoa); Đệ Nhị giáp Tiến sĩ xuất thân (Hoàng giáp); Đệ Tam giáp đồng Tiến sĩ xuất thân (gọi chung là Tiến sĩ); riêng triều Nguyễn có thêm Phụ bảng, những người thi đỗ tên ghi ở bảng này là Phó bảng. Điều chúng tôi muốn lưu ý là do thể lệ thi và chấm thi kỳ thi Đình dưới triều Nguyễn rất gắt gao và khắt khe nên không có người nào đạt điểm tối đa để nhận học vị đệ Nhất danh, tức Trạng nguyên. Tại khoa thi Ất Sửu (1865), Đình nguyên là Đệ Nhị giáp Tiến sĩ xuất thân (Hoàng giáp) Trần Bích San, còn Nguyễn Trọng Hiệp như trên có nêu chỉ thi đậu Đệ Tam giáp đồng Tiến sĩ xuất thân, tên ghi đứng đầu ở giáp thứ ba này, chứ không phải là Tiến sĩ đệ Nhất danh. Vấn đề học hành thi cử thời phong kiến, xin xem thêm: Phan Huy Chú, Lịch triều hiến chuoong loại chí, mục Khoa muc chí, bản dịch, Nxb Sử học, HN, 1961; Nguyễn Thị Chân Quỳnh, Khoa cư Việt Nam (Quyển hạ) Thi Hội; Thi Đình, Nxb Văn học và Trung tâm Nghiên cứu Quốc học, 2007; Nguyễn Công Lý - Ngô Văn Ban - Lê Trọng Ngoạn, Luợc khảo và tra cúu về Học chế - Quan chế ở Việt Nam tì̀ 1945 về trước, Nxb Văn hoá Thông tin, HN, 1997; Nguyễn Công Lý, Giáo dục - Khoa củ và Quan chế ở Việt Nam thời phong kiến, thời Pháp thuộc, Nxb ĐHQG TP. HCM, 2011.
} 
Tôn Thất Thuyết và phe chủ hòa với người đứng đầu là Nguyễn Văn Tường, Phan Thanh Giản. Hoạn lộ của Nguyễn Trọng Hiệp có thể nói là tương đối suôn sẻ, ông đã từng trải qua các chức vụ: Tổng đốc Định An, Tổng đốc Sơn Hưng Tuyên, Bắc kỳ Khâm sai quyền Kinh lược sứ, hàm Hiệp biện Đại học sĩ. Riêng dưới triều Đồng Khánh, ông đã là Hiệp biện Đại học sĩ lĩnh Thượng thư bộ Lại, sang triều Thành Thái thì ông là Phụ chính đại thần Hiệp biện Đại học sĩ, rồi Phụ chính đại thần Văn minh điện Đại học sĩ, lĩnh Thượng thư bộ Binh, sung Cơ mật viện đại thần, kiêm Tổng tài Quốc sử quán, kiêm quản Khâm Thiên giám sự vụ, được phong tước Vĩnh Trung tử. Với chức hàm này có nghĩa ông là một trong bốn vị đại thần (tứ trụ đại thần) ${ }^{5}$ giúp vua về chính sự ở Cơ mật viện. Nhiều lần ông được củ làm đại diện triều đình đi đón tiếp và nghị sự với các quan Toàn quyền Đông Dương. Ông còn được vua Thành Thái cử làm Chánh sứ mang quốc thư và phẩm vật đến thủ đô Paris nước Pháp để thông hiếu vào năm 1894. Tháng 11 năm Thành Thái thứ 8 (1896) khi Toàn quyền Đông Dương Phù Nam vương Rousseau ${ }^{6}$ mất, triều đình đã cử ông cùng với Phụ chính đại thần Võ hiển điện Đại học sĩ kiêm Kinh lược sứ Bắc kỳ Diên Mậu bá Hoàng Cao Khải mang lễ vật đến viếng tang. Khi ông mất, triều đình đã gia phong hàm Thái tử Thái bảo và truy thụ Cần Chánh điện Đại học sĩ, cấp tiền tuất 800 quan và sai mang văn tế tới phủ đệ của ông ở Bắc kỳ ban tế, lúc chôn cất chuẩn phái biền binh hộ tống, các quan viên nước Pháp cũng có nhiều người đến phúng viếng, tiếc thương?

Về trước tác, theo Trần Văn Giáp trong Luợc truyện các tác gia Việt Nam và các nhà nghiên cứu khác thì Nguyễn Trọng Hiệp đã để lại những tác phẩm sau:

Sách lịch sử: Minh Mệnh chính yếu; Đại Nam chính biên liệt truyện (sơ tập); Nhật lịch uớc biên; Đại Nam thưc luc chinh biên - đệ tư kỷ; Kim Giang Nguyễn tuoóng công nhật lịch tuỳ ký. Nhưng qua tra cứu, chúng tôi thấy quyển Kim Giang Nguyễn tuoóng

\footnotetext{
${ }^{5}$ Tứ trụ đại thần gồm 4 vị Đại học sĩ ở 4 điện là: Cần chánh điện, Văn minh điện, Đông các điện, Võ hiển điện, các vị được sung vào Co mật viện gọi là Co mật viện đại thần để lo về chính sự, giúp vua trị nước an dân, chỉ đạo các quan lại trong triều ngoài nội, bởi triều Nguyễn không lập Tể tướng, nên nhà vua mới dùng bốn vị này để chỉ đạo bá quan (xin xem thêm: Nguyễn Công Lý (2011), Giáo dục - Khoa củ và Quan chế ở Việt Nam thời phong kiến, thời Pháp thuộc, Nxb ĐHQG TP. HCM).

${ }^{6}$ Toàn quyền Đông Dương Rousseau được triều đình nhà Nguyễn lúc bấy giờ phong tước là Phù Nam vương.

${ }^{7}$ Theo Đại Nam thục luc chính biên đệ lục kỷ Phu biên, sđd, bản dịch, tr. 385-386.
}

công nhật lịch tuỳ ký là tác phẩm của con trai ông (tức Cử nhân Nguyễn Duy Nhiếp) ghi chép về ông, chứ không phải là trước tác của ông.

Sáng tác thơ văn: Kim Giang văn tập; Kim Giang thi tập; Tây tra thi thảo; Đại Pháp quốc Pa-ri đô thành tập vịnh.

\section{Tập thơ Đại Pháp quốc Pa-ri đô thành tập vịnh 大法國玻璃都城集詠}

3.1. Năm Giáp Ngọ (1894) Nguyễn Trọng Hiệp được vua Thành Thái (1869-1969; trị vì 1889-1907) cử làm đại diện triều đình nhà Nguyễn đi sứ sang thủ đô Paris nước Pháp để thông hiếu. Đoàn sứ bộ Đại Nam sang Pa-ri nước Pháp năm này gồm: Chánh sứ là Nguyễn Trọng Hiệp; Phó sứ là Tham tri bộ Lễ (gia hàm Thượng thư) Lê Bảng; Bồi sứ là Biện lý bộ Lễ Tôn Thất Thiệm, cùng các tùy thuộc là Tham biện Nguyễn Văn Mại; Chủ sự Nguyễn Văn Mẫn. Trong chuyến đi sứ này, Nguyễn Trọng Hiệp đã hoàn thành tập thơ Tây tra thi thảo 西查詩草, sách do Kinh đô Ấn thư đường khắc in tại Huế năm 1895, hiện lưu trữ tại Thư viện Viện Nghiên cứu Hán Nôm ký hiệu VHv 1411. Tập thơ gồm 68 bài, viết theo thể thơ bát cú và tứ tuyệt Đường luật, mà đa phần là thơ thất ngôn tứ tuyệt, đề tài chủ yếu là vịnh, tả cảnh vật như cảnh cửa biển Cần Giờ, Tân Gia Ba, cảng Cô-lôm-bô, Ấn Độ dương, E-ti-ô-pia, Y-ê-men, Hồng Hải, Địa Trung Hải, Kênh đào Xuy-ê, Thành Pa-ri, xem mặt trời mọc, đi xe máy lên núi, trong đó có 36 bài viết về đô thành Paris... Tập thơ được Tuy Lý Vương Miên Trinh và Hà Đình Nguyễn Thuật mỗi người đề một bài Tựa. Trong đó, có nhiều bài thơ được tác giả chú dẫn tỉ mỉ về các địa danh mà tác giả đã đi qua, nhờ vậy mà người đọc có thể hình dung về nơi chốn đó; có nhiều bài thơ được Tuy Lý Vương Miên Trinh phê điểm.

Tây tra thi thảo 西查詩草 gồm 3 quyển, có 68 bài, là tập thơ du ký, mang tính 'kỷ kiến', tức ghi chép lại những gì mắt thấy tai nghe mà tác giả đã mục kích chứng kiến. Điều thú vị là phần lớn các bài thơ đều được tác giả viết lời dẫn (lời ghi chú) với những ghi chép cụ thể về địa danh được vịnh tả, nhờ thế tập thơ đã cung cấp cho người đọc nhiều tri thức rất bổ ích. Có được tri thức này là bởi khi đi đến một nơi nào đó, Nguyễn Trọng Hiệp đều hỏi han tỉ mỉ về vị trí địa lý, đặc điểm khí hậu, phong tục tập quán ở nơi đó, rồi ghi lại chính xác. Chẳng hạn, khi phái đoàn sứ bộ đi đến cảng A-diên thuộc nước Cộng hòa nhân dân Y-ê-men, ông có làm bài thơ vịnh cảng A-diên với lời ghi chú cụ thể như sau: "Núi A-diên thế cao đột ngột, hiểm dũu, đất đỏ, không có cây cối, là cửa chắn của Hồng Hải. 
Thuyền bè qua lại Ân Độ tất phải theo con đuờng này. Nguòi Anh ở chỗ cao trên núi, xây dưng pháo đài, ngang núi lại khoét đuoòng để đi. Trong đồn binh trấn giũ có hai ngàn tên lính. Khí hậu noi này nóng, hai ba năm mói mưa một lần. Nguời Anh ở các núi đào ao khúc khuỷu, lợ dụng hang làm giếng. Gặp trời mưa, nuớc chứa trong hang, dùng gàu múc lấy nuớc ăn uống, tắm giặt, vất vả nhu vậy."8

Vào một buổi sáng sớm, trên vùng biển Nhật Bản, nghe tiếng gà gáy sáng, nhìn cảnh mặt trời mọc, Nguyễn Trọng Hiệp đã viết bài Thuyền lâu thuợng quan nhật xuất 船樓上觀日出 (Trên thuyền lầu xem cảnh mặt trời mọc), đây là bài thứ 2 của quyển một:

五夜天鷄唱,扶桑大海東.

乍驚雲氣爛,忽湧水心紅.

Ngũ dạ thiên kêxxuóng,/ Phù Tang đại hải đông.

Sa kinh vân khi lan,/ Hốt dũng thủy tâm hồng.'

(Canh năm gà gáy sáng,/ Phía đông biển lớn Phù Tang.

Mây thoắt tan khí trời tỏa sáng,/ Giữa mặt nước bỗng vọt lên một vừng hồng.)

Đoàn thuyền của sứ bộ cập cảng Cô-lôm-bô của quốc đảo Sri-lan-ka (Tích Lan), Nguyễn Trọng Hiệp viết bài Cô-lôm-bô áo 姑林逋澳 (Cảng Cô-lôm-bô) theo thể thất ngôn bát cú. Bài thơ gợi cho người đọc nhớ lại sự tích xa xưa nơi đất Phật, vừa giới thiệu đôi nét về cuộc sống nhộn nhịp của hiện tại. Hai câu kết, nhà thơ sứ giả bày tỏ lời nguyện cầu ánh sáng từ bi trí tuệ của Đức Phật soi chiếu khắp cả thế gian là xuất phát từ tâm tư, từ tấm lòng đậm tính nhân văn của tác giả khi đoàn sứ bộ đi qua miền đất của Phật giáo:

天臨印度見峰巒,雉堞參差俯碧灣.

漢使初通天答國,佛光今記錫蘭山。

樓含樹色千門出,街擁車聲八面環.

淨土豈知風物異,願憑慧日炤瀛富.

Thiên lâm Án Độ kiến phong loan,/ Trĩ điệp sâm si phủ bich loan.

Hán sư so thông Thiên Trúc quốc, / Phật quang kim ký Tích lan son.

Lâu hàm thu sắc thiên môn xuất,/ Nhai ủng xa thanh bát diện hoàn.

\footnotetext{
${ }^{8}$ Kim Giang Nguyễn Trọng Hiệp, Tây tra thi thảo, Ấn Thư Đường khắc in tại Huế năm 1895, Thư viện Viện Nghiên cứu Hán Nôm, ký hiệu VHv 1411, tờ 11b.

${ }^{9}$ Kim Giang Nguyễn Trọng Hiệp, Tây tra thi thảo, Ấn Thư Đường khắc in tại Huế năm 1895, Thư viện Viện Nghiên cứu Hán Nôm, ký hiệu VHv 1411, tờ 7b.
}

Tịnh độ khởi tri phong vật dị,/ Nguyện bằng tuệ nhật chiếu doanh hoàn. ${ }^{10}$

(Thấy gió và vịnh của rừng trời Ấn Độ,/ Từng vách thì lô nhô, nước biển phủ một màu xanh biếc./ Sứ nhà Hán [Trung Quốc] thông đường sang nước Thiên Trúc,/ Ánh sáng của Phật đã ghi lại ở núi Tích Lan này./ Sắc cây che lầu gác ngàn cửa ở ra,/ Đường sá rộn ràng tiếng xe cộ vây quanh tám mặt./ Mới biết cõi Tịnh độ phong vật xa lạ,/ Cầu xin ánh mặt trời trí tuệ soi chiếu khắp cõi thế gian.)

Kênh đào Suez (Xuy-ê, chữ Hán phiên âm là Tônhĩ-sĩ) là con kênh nhân tạo, nhằm rút ngắn lộ trình giao thông đường thủy ở châu Âu. Kênh do kỹ sư Phéc-đi-năng đờ Lét-xép (Ferdinand de Lesseps) thiết kế và chỉ huy công trình, mà tác giả đã ngợi ca ông này là 'người hùng kiệt' trong bài Tô-nhĩ-sĩ vận hà 蘇 爾士運河 theo thể cổ phong:

紅海彌天勢西注,平沙茫茫渺無路.

陡然一水當中通,兩岸黄埃雜煙霧.(...)

嘗聞斯土本大陸,地控二州古相屬.

舟航糿轉幾萬程,恨不長镜迎手熱.

豈無雄杰窮心思, (...)有人拔起西方濠.

Hồng Hải di thiên thể Tây chú,/ Bình sa mang mang diểu vô lộ.

Đồ nhiên nhất thủy đưong trung thông,/ Luõng ngạn hoàng ai tạp yên vu. (...)

Thưởng văn tu thổ bản đại luc,/ Địa khống nhị châu cổ tuoong thuộc.

Chu hàng vu chuyển kỷ vạn trình, / Hận bất truờng sàm nghênh thủ thuc.

Khởi vô hùng kiệt cùng tâm tu,(...) Hũu nhân bạt khởi Tây phương hào. ${ }^{11}$

(Biển Hồng Hải là vùng trời nước phía Tây,/ Bãi cát bằng mệnh mông không có con đường nào./ Một dòng nước chảy thông ngay ở giữa,/ Bụi vàng ở hai bên bờ sông như là khói sương mù./(...) Nghe nói nơi này vốn xưa là đất liền,/ Bao quát địa hạt cả hai châu lục./ Tàu thuyền phải đi quanh hành trình dài hàng vạn dặm./ Giận không khoét đất cho tàu thuyền vào./ Nếu không có người tài giỏi xuất sắc với suy nghĩ thấu đáo. /(...) [Thì đã] có người phương Tây đào hào sâu.)

\footnotetext{
${ }^{10}$ Kim Giang Nguyễn Trọng Hiệp, Tây tra thi thảo, Ẩn Thư Đường khắc in tại Huế năm 1895, Thư viện Viện Nghiên cứu Hán Nôm, ký hiệu VHv 1411, tờ 8a.

${ }^{11}$ Kim Giang Nguyễn Trọng Hiệp, Tây tra thi thảo, Ấn Thư Đường khắc in tại Huế năm 1895, Thư viện Viện Nghiên cứu Hán Nôm, ký hiệu VHv 1411, tờ 12b, 13a.
} 
3.2. Như đã giới thiệu, tập Tây tra thi thảo 西查詩 草 ở quyển 2 có 36 bài viết riêng về thủ đô Pa-ri, mà bản khắc in năm 1895 chỉ có phần thơ chữ Hán và ghi chú chữ Hán. Quyển 2 này có nhan đề là 大法國玻璃 都城集詠 (Đại Pháp quốc Pa-ri đô thành tập vịnh), từ tờ 17 đến tờ 32 của tập thơ. Đến năm 1897, tác giả tách ra để in thành một tập riêng, in theo công nghệ hiện đại lúc bấy giờ, do nhà in ty-pô li-tô $\mathrm{F}$. $\mathrm{H}$. Schneider, Hà Nội xuất bản như trên có nêu, bên cạnh thơ và ghi chú chữ Hán, thì bản in lần này có thơ và ghi chú bằng tiếng Pháp.

Nhan đề tiếng Pháp của tập thơ là Paris capitale de la France - Recueil de vers (Tuyển tập thơ vịnh về thủ đô Pa-ri của nước Pháp); nhan đề chữ Hán là 大法 國玻璃都城集詠 (Đại Pháp quốc Pa-ri đô thành tập vịnh). Bên cạnh nhan đề, trang bìa ruột của tập thơ có ghi：文明殿大學士永忠子金江阮仲合著 Văn minh điện Đại học sĩ Vĩnh Trung tủ Kim Giang Nguyễn Trọng Hiệp truớc. (Đại học sĩ ở điện Văn minh tên là Nguyễn Trọng Hiệp, tước Vĩnh Trung tử, hiệu Kim Giang, sáng tác).

Tất cả 36 bài đều viết theo thể thơ thất tuyệt, tập trung tả vịnh những danh thắng của thủ đô nước Pháp, từng bài không có đầu đề, chỉ đánh số thứ tự từ 1 đến 36 , tất cả đều mang giọng điệu tụng ca. Sau đây xin được giới thiệu một số bài trong tập thơ song ngũ Pháp - Hán này.

Mở đầu tập thơ là bài giới thiệu về lịch sử thành lập nước Pháp cách đây cả ngàn năm:

I.

Clovis fonda un Etat puissant sur des bases très solitdes.

Il y a plus de miles ans, dans cette contrée si belle et si riche.

Notre mission y est arrivée juste au printemps quand l'air est précisément bien doux.

Dès ma descente de voiture, je me lais un devoir de chanter l'illustre capitale.

(Bài 1. Hoàng đế Clovis đã xây dựng một quốc gia với nền tảng hùng mạnh vững chắc,/ Cách nay trên 1000 năm, trong miền đất tráng lệ và giàu có này./ Chúng tôi đã có chuyến sứ trình tới đó vào giữa mùa xuân, khí hậu hết sức mát mẻ trong lành./ Ngay khi bước xuống khỏi xe, tôi tự cho mình có bổn phận phải ca ngợi thành đô lộng lẫy này.)

\footnotetext{
其一

哥羅立國振雄圖.千有餘年富麗區.
}

使節正逢春氣暇, 停車謚合賦名都. ${ }^{12}$

Kỳ nhất

Ca-la lập quốc chấn hùng đồ,/ Thiên hưu du niên phú lệ khu.

Sứ tiết chánh phùng xuân khí hạ,/ Đình xa ích hợp phú danh đô.

Bài 2 miêu tả quang cảnh tổng quát của thủ đô Pari, nơi được thế giới ngợi ca, mệnh danh là kinh đô ánh sáng:

II.

Des palais et des hôtels magnifiques reposent leur superbe toiture dans la voute azurée.

Comme un ruban d'argent un fleuve au caux lustrées coule à travers la ville.

Il y a des promenades charmants qui éveillent aux voyageurs des élans virils.

Toutes les nuits des milliers de lumières brillent entre les vingt-quatre points.

(Bài 2. Lâu đài, dinh thự nguy nga vươn mái ngói lên bầu trời xanh biếc,/ Như một dải băng trắng, dòng sông Seine nước trong vắt chảy ngang thành phố./ Những cuộc dạo chơi thú vị khơi gợi nơi du khách tinh thần đam mê mãnh liệt./ Đêm đêm hàng ngàn đèn sáng chiếu rọi rực rỡ giữa hai mươi bốn cây cầu.)

其二

城關參差倚碧霄, 銀流一带水迢迢.

幾多遊賞增豪氣, 夜夜燈光廿四橋. ${ }^{13}$

Kỳ nhị

Thành khuyết sâm si ỷ bích tiêu,/ Ngân luu nhất đái thủy thiều thiều.

Kỷ đa du thưởng tăng hào khí,/ Da dạ đăng quang trấp tứ kiều.

Bài 3 tác giả miêu tả đường phố ở Pa-ri rộn ràng, nhộn nhịp với xe cộ và dòng người qua lại tấp nập:

III.

De tous côtés la circulation des voitures dans les rues soulève la poussière en une sorte de brouillard irisé.

Des défilés ininterroompus des prom neurs vont et viennent sans cesse.

\footnotetext{
${ }^{12}$ Paris capitale de la France - Recueil de vers (大法國玻璃都城集 詠) Hanoi - Imprimerie Typo - Lithographque F. H. Schneider, 1897.

${ }^{13}$ Paris capitale de la France - Recueil de vers (大法國玻璃都城集 詠) Hanoi - Imprimerie Typo - Lithographque F. H. Schneider, 1897.
} 
Cette animation rend l'air chaud, on doit avoir basion des douches (ou remèdes réfrigérants).

Heureusement il y a des milliers de fontaines dont l'eau jaillissante rafratchit l'atmosphère chargée.

(Bài 3. Mọi nẻo đường, tấp nập trên phố những dòng xe cuốn theo cát bụi tựa sương mù lấp lánh./ Những dòng người dạo phố nối tiếp nhau không ngừng./ Cảnh linh động này tạo thêm bầu khí nóng nực,/ May thay, hàng nghìn đài nước làm dịu không khí.)

其三

四望車塵滾地紅, 遊人络繹九衘中.

煩襟擬借清凉散, 百道飛泉寫遠空. ${ }^{14}$

Kỳ tam

Tư vọng xa trần cổn địa hồng,/ Du nhân lạc dịch củu cù trung.

Phiền khâm nghĩ tá thanh lương tản,/ Bách đạo phi tuyền tả viễn không.

Bài 4 tác giả tả lại quang cảnh thủ đô Pa-ri về đêm với đèn điện rực sáng thông qua sự liên tưởng thật thú vị:

IV.

Que de jolie maisons, que de beaux hôtels, se suivent et se lient en longues chaitnes.

Au coucher du soleil le bruit des voitures gronde encore.

Soudain, on est surpris de voir les étoiles tombées de l'espace.

Car des milliers de lumières brillantes viennents empêcher l'effet des ténèbres de la nuit.

(Bài 4. Bao la những toà nhà, những khách sạn nối nhau thành từng dãy dài./ Hoàng hôn đến, vẫn còn náo nhiệt tiếng xe./ Từ khung trời bỗng dưng thấy xuất hiện những vì sao,/ Với muôn ngàn ánh sáng chiếu tỏa xóa đêm đen.)

其四

複閣層樓遠接連,夕陽車馬尚喧輇.

忽疑星斗空中落, 萬盛燈光不夜天. ${ }^{15}$

Kỳ tứ

Phức các tằng lâu viễn tiếp liên,/ Tịch duoong xa mã thương huyên thuyên.

Hốt nghi tinh đẩu không trung lacc,/ Vạn trản đăng quang bất dạ thiên.

\footnotetext{
${ }^{14}$ Paris capitale de la France - Recueil de vers（大法國玻璃都城集 詠) Hanoi - Imprimerie Typo - Lithographque F. H. Schneider, 1897.

${ }^{15}$ Paris capitale de la France - Recueil de vers (大法國玻璃都城集 詠) Hanoi - Imprimerie Typo - Lithographque F. H. Schneider, 1897.
}

Dịch thơ:

Gác lớn lầu cao nối tiếp liền, Chiều tà xe ngưa rộn huyên thuyên.

Bồng ngò̀ sao rụng trên trời xuống, Đèn sáng, trời không biết có đêm.

Bài 32, tác giả ca ngợi tính chất hiện đại của hệ thống ngân hàng của nước Pháp:

\section{XXXII}

Sous les dynasties de Tống et de Nguyên, on avait mis des billets de banque en circulation.

Mais ce systèmes n'était pas aussi parfait et aussi estimable que le système moderne si sépandu en Europe.

Et qui est si prolitable aux transactions $d u$ commerce aussi bien qu'aux finances des gouvernements.

(Bài 32. Dưới thời nhà Tống và nhà Nguyên,/ Người ta đã cho lưu hành những ngân phiếu./ Nhưng hệ thống này đã không hoàn hảo và có giá trị như hệ thống hiện đại rất phổ biến tại Châu Âu./ Và nó rất tiện ích cho giao thương cũng như cho ngân sách của các chính phủ.)

其三十二

歷求鈔務宋元初, 輕重權來尚覺疎.

今日通行泰西法, 源源黄白佐邦儲. ${ }^{16}$

Kỳ tam thập nhị

Lịch cầu sao vu Tống Nguyên so;/ Khinh trọng quyền lai thuợng giác so:

Kim nhật thông hành thái Tây pháp,/ Nguyên nguyên hoàng bach tá bang trù.

Bài 34 ca ngợi đài Thiên văn ở thủ đô Pa-ri với chức năng hoàn hảo diệu kỳ của nó, mà đài Thiên văn của Trung Quốc cũng không thể nào sánh bằng:

\section{XXXIV}

Le Chapitre Thuấn điển, du Thu kinh parle de l'appareil de perles et du tube de pierre précieuse inventés par la anciens pour observer le mouvement du soleil.

A l'époque de Minh, l'astronomie curopéenne fut introduite en Chine.

L'Observatoire de Paris possède des instruments astronomiques d'une perfection merveillense.

\footnotetext{
${ }^{16}$ Paris capitale de la France - Recueil de vers (大法國玻璃都城集 詠) Hanoi - Imprimerie Typo - Lithographque F. H. Schneider, 1897.
} 
Cependant le comput de deux calendriers, grégorien et chinois, est calcuté d'après la rotation des astres autour du ciel.

(Bài 34. Chương Thuấn điển của Kinh Thu nói về máy ngọc và ống đá quý được người xưa khám phá ra để quan sát sự chuyển động của mặt trời,/ Thời nhà Minh, thiên văn được du nhập vào Trung Hoa./ Đài Thiên văn Paris có những thiết bị thiên văn hoàn hảo diệu kỳ./ Tuy nhiên cách tính hai lịch, Grê-goa (lịch nước Pháp) và Trung Hoa, lại dựa trên sự chuyển động của các thiên thể xung quanh mặt trời.)

其三十四

七政璇璣帝典垂, 前明西學益參推.

即今儀器窮精妙, 猶想周天定歲差. ${ }^{17}$

Kỳ tam thập tứ

Thất chính tuyền co đế điển thùy,/ Tiền Minh, Tây hoc ich tham thôi.

Tức kim nghi khí cùng tinh diệu,/ Do tưởng châu thiên định tué sai.

\section{Kết luận}

Tóm lại, qua giới thiệu sơ lược về hành trạng sự nghiệp của Kim Giang Nguyễn Trọng Hiệp và đôi nét về tập thơ 大法國玻璃都城集詠 Đại Pháp quốc Pa-ri đô thành tập vịnh, có thể nói trong tình hình tư liệu hiện nay, Nguyễn Trọng Hiệp là tác giả Việt Nam đầu tiên trong văn học cổ điển/trung đại Việt Nam sử dụng song ngữ Pháp - Hán để sáng tác thơ. Về quan điểm, so với đội ngũ trí thức nho học quan lại cùng thời thì Nguyễn Trọng Hiệp có cái nhìn rộng mở, thể hiện tinh thần cầu tiến, ham học hỏi cái mới cái lạ của xứ người để nhằm phổ biến làm giàu cho tri thức ở ta. Hiện tượng sáng tác song ngữ này bước đầu đã đặt nền móng, khơi nguồn cho giao lưu văn hóa, văn học Việt - Pháp ở giai đoạn đầu tiên, lúc nước nhà bị Pháp thuộc.

\section{TÀI LIỆ THAM KHẢO}

1. 西查詩草, 京都印書堂, 文明殿大學士永忠子 金江阮仲合著，成泰甲午孟秋，Ký hiệu VHv 1411， Thư viện Viện Nghiên cứu Hán Nôm;

2. 大法國玻璃都城集詠, “Paris capitale de la France - Recueil de vers” 文明殿大學士永忠子金江
阮仲合著, Hanoi - Imprimerie Typo - Lithographque F. H. Schneider, 1897;

3. Quốc sử quán triều Nguyễn (2011), Đại Nam thục lục chính biên đệ lục kỷ Phu biên, Cao Tự Thanh dịch và giới thiệu, Nxb Văn hoá - Văn nghệ Tp. HCM;

4. Hội Sử học Hà Nội (1996), Nguyễn Trọng Hơp con người và sụ nghiệp, Nxb Hà Nội;

5. Phan Huy Chú (1961), Lịch triều hiến chuoong loại chí, mục Khoa muc chí, bd, Nxb Sử học, Hà Nội;

6. Trần Văn Giáp (chủ biên), Nguyễn Tường Phượng, Nguyễn Văn Phú, Tạ Phong Châu, Đỗ Thuận (1972), Luợc truyện các tác gia Việt Nam, tập 1, 1962; tập 2, Nxb KHXH, Hà Nội;

7. Nguyễn Công Lý (2011), Giáo duc - Khoa cử và Quan chế ở Việt Nam thời phong kiến, thời Pháp thuọc, Nxb ĐHQG TP. HCM;

8. Nguyễn Văn Mại (1960), Lô Giang tiểu sủu, Bản Việt dịch của Nguyễn Hy Xước 1947, In ronéo tại Huế đầu những năm 1960;

9. Trần Nghĩa - François Gros (1993), Di sản Hán Nôm Việt Nam: thu muc đề yếu, Tập 3, Nxb KHXH, Hà Nội.

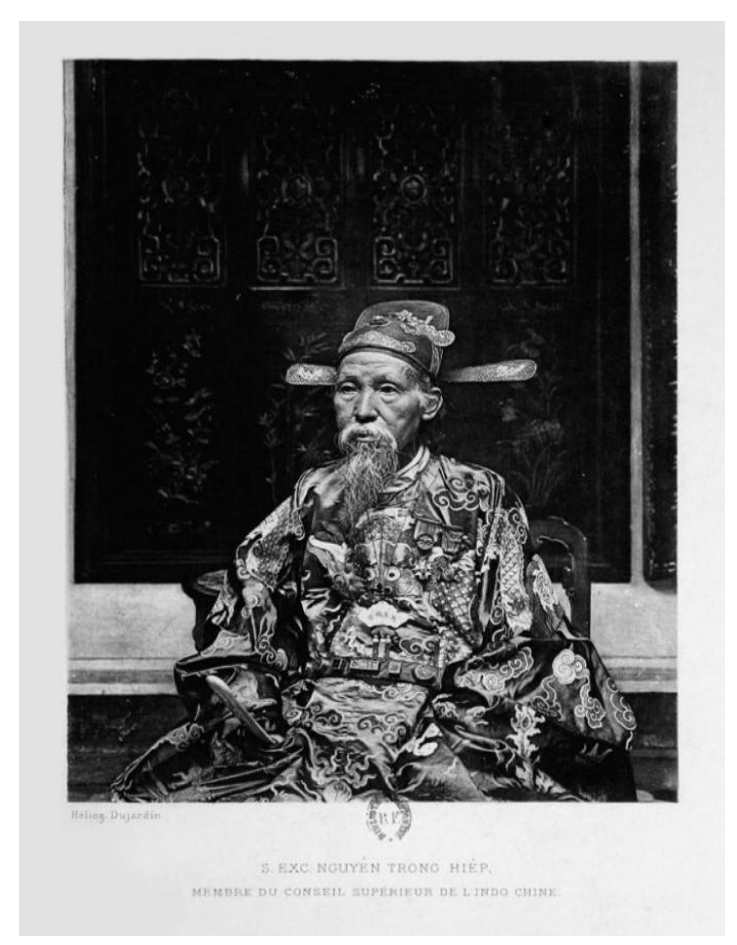

Chân dung tác giả Nguyễn Trọng Hiệp

${ }^{17}$ Paris capitale de la France - Recueil de vers (大法國玻璃都城集 詠) Hanoi - Imprimerie Typo - Lithographque F. H. Schneider, 1897. 

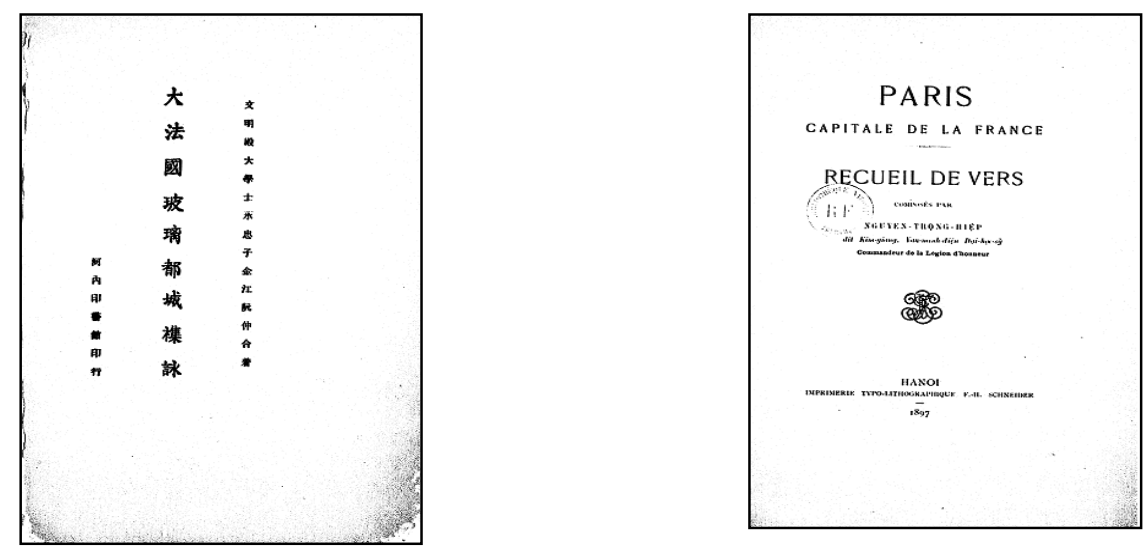

\section{Composing bilingual Franco-Shino: a unique phenomenon in Vietnamese literature in second half of nineteenth century}

Nguyen Cong Ly

\section{Article info}

Recieved:

16/02/2018

Accepted:

$10 / 3 / 2018$

\section{Keywords:}

French-Shino bilingualism, Nguyen Trong Hiep, Paris capital of France - collection of verses, Chief Mission to France written in 1894, published in 1897.

\begin{abstract}
Writing in bilingual is not uncommon in literature in Vietnam and in the world. Particularly, in Vietnam, from the early eighteenth century to the late nineteenth century, many authors have written in Shino characters and then translated into Nôm, or vice versa, or alternating Han - Nom. But writing in Shino characters and then translated into French, then published into a collection, printed in modern technology, is a rare case, unique and unprecedented, that Nguyen Trong Hiep can be the author pioneer of this phenomenon. This article will introduce the case in the French-Chinese bilingual book "Paris capital of France - collection of verses" writen by Nguyen Trong Hiep in 1894 during his visit to France as the chief of Ambassador and was published in 1897.
\end{abstract}

\section{Auteur bilingue Franco - Shino: un phenomene unique dans la litterature Vietnam en fin du $x{ }^{\mathrm{e}}$ siecle}

\section{Sommaire}

Ecrire en bilingue n'est pas rare en littérature dans notre pays et dans le monde. En particulier au Vietnam depuis le début du XVIII ${ }^{\mathrm{e}}$ siècle à la fin du XIX ${ }^{\mathrm{e}}$ siècle, de nombreux auteurs écrivant en chinois et traduit le script lui-même, ou vice versa, ou alternatif Han - Nom. Mais l'écriture en Shino et traduit en Français et publié en volumes, conformément à la technologie moderne est un cas rare, unique, jamais vu auparavant, mais Nguyen Trong Hiep peut l'auteur pionnier de ce phénomène. Cet article présentera l'événement a recueilli plus de poèmes bilingue français - chinois "Paris capitale de la France - Recueil de vers" par Nguyen Trong Hiep en 1894 au cours d'une visite de fonctionnaires en France comme chef de l'Ambassadeur, et publié en 1897.

Mots clés: Bilinguisme Franco-Shino; Nguyen Trong Hiep; Paris capitale de la France - Recueil de vers; Mission principale en France; écrit en 1894; publié en 1897. 